\title{
Decolonizing Trauma Studies Round-Table Discussion
}

\section{Stef Craps ${ }^{1}$, Bryan Cheyette ${ }^{2}$, Alan Gibbs ${ }^{3}$, Sonya Andermahr ${ }^{4}$ and Larissa Allwork ${ }^{5, *}$}

1 Department of Literary Studies, Ghent University, Blandijnberg 2, 9000 Gent, Belgium; E-Mail: stef.craps@ugent.be

2 Department of English Literature, University of Reading, Whiteknights, Reading RG6 6AA, UK; E-Mail: b.h.cheyette@reading.ac.uk

3 School of English, O’Rahilly Building, University College Cork, Cork, Ireland; E-Mail: a.gibbs@ucc.ie

4 English Division, The School of The Arts, The University of Northampton, Avenue Campus, St. George's Avenue, Northampton NN2 6JD, UK; E-Mail: Sonya.Andermahr@northampton.ac.uk

5 School of History, University of Leicester, University Road, Leicester, LE1 7RH, UK

* Author to whom correspondence should be addressed; E-Mail: 1fa5@leicester.ac.uk; Tel.: +44-(0)-116-252-2736.

Academic Editors: Gail Finney and Doug Davis

Received: 18 September 2015 / Accepted: 19 November 2015 / Published: 30 November 2015

Abstract: This round-table, which featured literary critics Professor Stef Craps, Professor Bryan Cheyette and Dr. Alan Gibbs, was recorded as part of the "Decolonizing Trauma Studies" symposium organized by Dr. Sonya Andermahr and Dr. Larissa Allwork at The School of The Arts, The University of Northampton (15 May 2015). Convened a week after the University of Zaragoza's "Memory Frictions" conference, where Cheyette, Gibbs, Andermahr and Allwork gave papers, the Northampton symposium and round-table was sponsored by The School of The Arts to coincide with Andermahr's guest editorship of this special issue of Humanities. Craps, Cheyette and Gibbs addressed five questions during the round-table. Namely, does trauma studies suffer from a form of psychological universalism? Do you see any signs that trauma studies is becoming more decolonized? What are the challenges of a decolonized trauma studies for disciplinary thinking? How does a decolonized trauma studies relate to pedagogical ethics? Finally, where do you see the future of the field? While this edited transcript retains a certain informality of style, it offers a significant contribution to knowledge by capturing a unique exchange between three key thinkers in contemporary trauma studies, providing a timely analysis of the impact of 
postcolonial theory on trauma studies, the state of the field and its future possibilities. Issues addressed include the problematic scholarly tendency to universalize a western model of Post-Traumatic Stress Disorder (PTSD); the question of the centrality of the Holocaust in trauma studies and the implications of this for the study of atrocities globally; the vexed issues posed by the representation of perpetrators; as well as how the basic tenets of western cultural trauma theory, until recently so often characterized by a Caruth-inspired focus on belatedness and afterwardness, are being rethought, both in response to developments in the US and in answer to the challenge to 'decolonize' trauma studies.

Keywords: decolonizing; disciplinary thinking; Holocaust; pedagogy; PTSD; trauma; trigger warnings

Larissa Allwork: It has been a fantastic day of papers, and we are going to finish with a very special round-table on the theme of the symposium, which is "Decolonizing Trauma Studies" [1]. Commenting on the questions that we are going to cover are Professor Stef Craps, our keynote speaker, author of Postcolonial Witnessing: Trauma out of Bounds [2] and Director of the Cultural Memory Studies Initiative at Ghent University. Joining him will be Professor Bryan Cheyette, who is Chair in Modern Literature at the University of Reading. He is the editor or author of nine books, most recently Diasporas of the Mind [3] and Volume Seven of the Oxford History of the Novel in English [4], which is forthcoming with Oxford University Press. We are also very happy to welcome Dr. Alan Gibbs, who is Lecturer in American Literature at University College Cork. He has recently written on trauma theory and cultural representations, and in 2014 published Contemporary American Trauma Narratives [5]. So, without further ado, I am going to hand over to Dr. Sonya Andermahr, who will ask the questions.

Sonya Andermahr: We are going to start off with an issue that's been bubbling through our discussions all day. It concerns the relationship between individual and collective traumas when we are discussing non-western and minority cultural groups. So the question is, do trauma studies suffer from a form of psychological universalism, in your opinion?

Alan Gibbs: The short answer would be yes. I think that it's well established that this is a problem with the cultural trauma model, and with the model of PTSD widely disseminated through DSM-III [6]. I'm thinking back to Allan Young's book, The Harmony of Illusions, which amazingly was published 20 years ago now [7]. It points out the problem that PTSD is taken to be this kind of timeless, universal way in which we understand trauma, when in fact Young does a very able job of showing how trauma is pieced together from various contemporary discourses and ideologies. I agree with him. I think there are multiple problems of taking this 
relatively temporally and geographically local phenomenon of PTSD and trying to universalize it.

There are also problems in the treatment of trauma, and Derek Summerfield has pointed this out, that there is a kind of 'neo-colonialism' if you like, of exporting notions of PTSD [8]. I think, Stef, you've talked about this in your work. For example, the problems with western aid workers going into Sri Lanka after the 2004 Tsunami and using their methods to try to treat trauma ([2], pp. 22-23). I think there are also problems in my field, literary studies, of trauma studies - perhaps as part of its attempt to connect disciplines - actually having a colonial mode itself, in trying to dominate other disciplines, across other disciplinary boundaries. These represent problems of trauma theory extending its purview beyond where it operates convincingly. Just to finish, I'll give an example. I remember a paper I heard three or four years ago at a conference on literary representations of trauma. This paper examined ancient Greek literature and the presenter argued that the descriptions of the soldiers post-battle portrayed them as having this "thousand yard stare" and therefore they could be diagnosed as suffering from PTSD. This strikes me as dangerous and presumptuous, to homogenize history in this way, to suggest that humans have always suffered in the same way from trauma. It has a number of implications, but I think that this is something we should further explore.

Stef Craps: $\quad$ I haven't got too much to add, actually, to what Alan has just said. That trauma studies suffers from psychological universalism is one of the key criticisms that I level in my book [2]. I argue that yes, it is important for trauma studies to look beyond the Euro-American context and to pay more attention to the traumas associated with colonialism, for example. However, that in itself does not suffice. Because if you're going to impose a western framework on these other histories, you may end up distorting them, so you may be doing more harm than good. In other words, decolonizing trauma studies is not just about expanding the scope, broadening the focus, but also about critically examining and revising dominant conceptions of trauma and recovery.

This is a task not only for cultural trauma theory, but also for psychological trauma research. Among psychologists, concerns have been raised about the PTSD construct, as Alan has already pointed out, and alternative paradigms have been proposed. However, none of this seems to have had much of an impact on the field of cultural trauma research. The impact of different cultural traditions on the way trauma is experienced and on the process of healing is rarely acknowledged. Trauma theory for the most part continues to adhere to the traditional, event-based model of trauma, according to which trauma results from a single, extraordinary, catastrophic event, and recovery takes the form of the talking cure. So, in a sense, the situation in the field of cultural trauma research is even more dire than that in the field of psychological trauma research, because 
recent insights from the latter field - in which there is a growing awareness, at least, of the need to move beyond psychic universalism - aren't even taken up in the former field. Or, that is, they weren't until very recently.

Bryan Cheyette: For some historical perspective, I would add the figure of Frantz Fanon, who in 1952 in Black Skin, White Masks was already critiquing the Freudian analysis of trauma for being Eurocentric and ignoring Africa [9]. He very much wanted to construct a 'black psychiatry' against dominant modes, which he eventually put into practice in Tunisia and Algeria. The complicating factor is that within Fanon's early critique of Eurocentric psychiatry, there are all kinds of representations that you would not actually want there, such as the mind/body opposition or a disdain for homosexuality and a validation of masculinity. But this was an early critique which shows that, from an anti-colonial perspective, trauma studies has a long history of being thought of as Eurocentric.

Sonya Andermahr: Moving on then to the next major question that we've been exploring in today's symposium: do you see any signs that trauma theory is becoming more decolonized?

Stef Craps: $\quad$ I would say so, yes, judging from the number of publications on colonial trauma and postcolonial trauma theory that have appeared in recent years and the number of conferences and panels that have been devoted to these issues, including this symposium. It struck me, for example, that moving beyond Eurocentrism is the most pronounced trend that can be seen in recent collections which try to take stock of the state of the art of research in the field of trauma studies. I'm thinking of The Future of Trauma Theory [10] and Contemporary Approaches in Literary Trauma Theory [11]. Both of these collections contain several essays whose explicit purpose is to decolonize trauma studies.

At the same time, though, my sense is that we're only at the beginning of this process. That's also where I would situate my own work in this area. What I do in my Postcolonial Witnessing book [2] is diagnose a problem but not so much remedy it. That is one of the no doubt many limitations of the book. I don't want to generalize, but to some extent I think this is symptomatic of the phase we're in. I have tended to focus on literary texts that highlight the shortcomings of the dominant trauma discourse, for example Sindiwe Magona's novel Mother to Mother [12] and, more recently, Aminatta Forna's novel The Memory of Love $[13,14]$. These are texts by postcolonial writers who, however, are steeped in western culture, who write in English, and who address a western audience first and foremost. They invest considerable energy in pointing out the inappropriateness and the injustice of applying western frameworks to a colonial or postcolonial situation, but they are less concerned with offering a concrete alternative.

That's the next step, I think: once the critique is out of the way, we can start examining what an alternative to the dominant trauma discourse might look like in 
practice, on the ground, in particular non-western or minority contexts. It's been very gratifying to see that my work has been taken up by other scholars, especially $\mathrm{PhD}$ students, who are doing just that. I think it's important to study how the cultural production of particular non-western or minority groups bears witness to painful histories. This requires specialized knowledge of these other cultures and languages, of the different media and forms of expression they use, and of local beliefs about suffering and healing. So I think that's where we're headed.

Bryan Cheyette: In my case, a teaching and research interest in Holocaust testimonies came before an interest in trauma theory. I now recognize that the Holocaust has been the dominant trauma discourse, but what Michael Rothberg calls the 'colonial turn' within Holocaust studies has been very important for the decolonizing process which Stef describes [15]. The danger, and maybe I'll talk more about this a little later, is of having a supersessionist model which constructs the Holocaust as the classic expression of trauma that, as a consequence of this model, has to be transcended by newer instances. That model comes up in all kinds of other disciplines; ethnic and racial studies, diaspora studies, even postcolonial studies. Also problematic is the oft-made assumption that the Holocaust is wholly Eurocentric which should be at least complicated. However, there's a clear consensus to decolonize, not just trauma studies, but all disciplines. Edward Said even argued that postcolonial studies needed to be decolonized as well, but the kind of new work that is being produced, much of it by younger scholars and $\mathrm{PhD}$ students, shows that we are very much moving in the right direction.

Stef Craps: $\quad$ Could you elaborate on your point that the assumption that the Holocaust is wholly Eurocentric is problematic? After all, it was a genocide that took place in Europe and was committed by Europeans against other Europeans.

Bryan Cheyette: Obviously, the camps were based in Europe, but, to answer your question in full, I would recommend Mark Mazower's Hitler's Empire, which shows that the Holocaust was a continuation of the colonial project [16]. This argument reinforces the early anti-colonial critiques of Aimé Cesaire [17] and Hannah Arendt, who, reflecting many others in the 1940s and 1950s, saw Nazi atrocities as colonialism brought home to Europe [18]. What Mazower shows is that the Nazis looked to two main colonial projects as a model for their intended colonization of the European continent. Firstly, the growing power and influence of North America was seen to be a consequence of the colonization of the American continent (North and South). The Nazis also saw British colonies in Africa and Asia, which they witnessed first-hand, as a model for their own project of colonizing Europe. There's a wealth of historical detail in Mazower to show that a number of Nazis in Eastern Europe were trained in Africa, especially in West Africa ([16], pp. 581-88). The book also illustrates the tensions between a colonial model of the camps, based on slave labour, and an exterminatory model based on 'race' theory. So there are a large number of connections between the 
camps and colonialism. Also, of course, the Nazi genocide extended outside of Europe to North Africa especially. So there are all kinds of ways of thinking of the colonial turn historically as well as complicating present-day Eurocentric understandings of the Holocaust.

What I would argue, in terms of my own work on disciplinary thinking, is that up until the 1960s, in relation to an anti-colonial critique, none of these areas were separated out; they were seen as part of the same history: colonialism, fascism, genocide, racism. So it's really only after the 1960s that discussion of these areas began to be 'disciplined'. A figure like Fanon, for example, was influenced enormously in his thinking by issues of anti-Semitism through the work of Jean-Paul Sartre, but also in relation to his own experience as a soldier fighting against fascism. As a result, it seems to me that the assumption that the Holocaust, its causes, history and legacies, are largely Eurocentric needs to be questioned.

Alan Gibbs: I would just add a couple of things. It is interesting that we are looking at this from different perspectives. Bryan, you're coming at this from the Holocaust studies perspective, and my background is very much in American literature and American studies. What has been really interesting for me has been seeing the impact of postcolonial studies on trauma studies most recently. I think getting back to the original question: yes, I would agree that in the last few years there are many signs that theory is becoming more decolonized. There is much more consciousness of the variety of manifestations of trauma. There is more sensitivity to localized variations in causes and symptomatology and treatment and, especially interesting for me, the representation of trauma.

There is also more sensitivity to phenomena such as insidious trauma, and ideas to do with slow violence. This has had an impact on the way trauma theory and trauma studies are considered in the American context. One of the things that I have been arguing is that this set of cultural trauma theories that have become so dominant are not only inadequate for the postcolonial experience but even for many representations in fairly mainstream American writing as well. What I argue in Contemporary American Trauma Narratives is that these dominant trauma paradigms do not even necessarily work in the contemporary American context [5].

Bryan Cheyette: I agree absolutely with you, Alan. In Diasporas of the Mind, I have a chapter on Philip Roth, and I argue that there's a shift in most of his late fiction, particularly after Sabbath's Theatre [3,19]. After this novel, Roth begins to write from a national perspective (rather than a diasporic perspective), and as a result, locates issues of trauma and suffering within the post-war history of the United States rather than as part of European history as he did in his earlier fiction. As a result, his fiction has become rather earnest. In The Plot Against America, for instance, Roth holds back the more extreme implications of his narrative of American fascism as it only makes sense in a European context [20]. The notion of a 
traumatized nation, post 9/11, in the US is central to Roth's late fiction, which has been surprisingly well-received given the geopolitical consequences of such national trauma.

Alan Gibbs: $\quad$ Yes, I think so, and I also think that some of the creative and critical writing that has been published since $9 / 11$ has shown the inadequacy of very narrow definitions and narrow prescriptions about the aesthetic representation of trauma. A lot of writers have really strained against that post 9/11.

Stef Craps: I want to briefly come back to Alan's point about insidious trauma in the American context. I think there has indeed been a tendency to map the event-based model of trauma onto western experiences and to assume that insidious trauma is what happens elsewhere. I agree that that's reductive. For example, the Holocaust is often discussed in terms of the event-based model, but does it really make sense to think of it as a single catastrophic event? It lasted five years or so and encompassed lots of different kinds of events and experiences; it's hardly a straightforward case of punctual trauma, let alone a textbook example.

Alan Gibbs: $\quad$ Well this is what always surprises me about how dominant that punctual model has become, given that the Holocaust is so much at the root of trauma studies. But yes, absolutely, there are insidious traumas at the heart of American life as well. So again that model does not fit so well there. There is one other thing I would just point out which occurred to me during Sonya Andermahr [21] and Béatriz Perez Zapata's [22] panel today, in terms of getting away from these kinds of dominant models, which I thought was very interesting. Sonya and Béatriz were both talking about how Zadie Smith [23] and Andrea Levy [24] adopt some of this postmodernist trauma aesthetic but were also much more interested in how these authors violate that aesthetic, and how they go beyond it. Now this seems to me quite a significant step forward from a lot of papers and articles that I've encountered over the last few years which frequently perform a fairly formulaic checklist criticism which evaluates the extent to which a particular writer lives up to how trauma should be represented. I thought it was really interesting that you both took a much different approach this afternoon.

Sonya Andermahr: We knew who was going to be listening (Laughter). The next question, suggested by Bryan, concerns disciplinary thinking and the implications and challenge of a decolonized trauma theory for our understanding of our own disciplines and their relations to others. Bryan, would you like to lead on this?

Bryan Cheyette: Yes, this is a key argument in Diasporas of the Mind which goes back to the period of decolonization after the Second World War from the 1940s to the early 1960s. At this time there wasn't the kind of disciplinary thinking which put different national and ethnic histories into separate spheres that we have now. That seems to me to be a period that is well worth exploring as the connections between the history of genocide in Europe and European colonialism are made 
throughout by anti-colonialists as well as Holocaust survivors, which is why scholars have gone back to Hannah Arendt [18] especially. Disciplinary thinking, on one level, is a way of thinking critically about academic disciplines. My argument is that academic disciplines are constructed increasingly in terms of what they leave out, and defined by what they exclude. Jonathan Boyarin has argued this ([25], p. 172), as has Gayatri Spivak, who talks about "disciplinary fear" [26]. The problem with knowing more and more about less and less is that it can lead to a lack of interconnectedness across disciplines.

New comparative studies and a focus on interconnected histories has certainly helped to move us away from insular and 'disciplined' histories of victimization. Currently, the model that a lot of books address, including your book, Stef [2], is the dialogue between postcolonial studies and Jewish studies, and that can take us in lots of different directions. One example that I use in my book [3] is the figure of Edward Said, who, towards the end of his life, wrote about quite a number of Jewish exiles from Nazism, such as Theodor W. Adorno and Sigmund Freud. In his famous interview, which ends his large book of interviews, Said described himself as the "last Jewish intellectual", a "Jewish Palestinian" and the "only true follower of Adorno" ([27], p. 458). Said did this because he wanted Palestine, and present-day issues of colonialism in Palestine, to be part of postcolonial studies, and, for this reason, he wanted the connection to be made between the history of Nazism and the history of Palestine. He went back to Hannah Arendt, for instance, in his book on the question of Palestine [28] to make this point. Historically, it doesn't make sense separating out these histories, and Said understood this.

Related to disciplinary thinking is the question of supersessionist thinking which I addressed at the University of Zaragoza's "Memory Frictions" conference [29]. Such thinking goes back to Robin Cohen's Global Diasporas [30], for instance, where the Jewish diaspora is constructed as the classic diaspora, which is then superseded by newer, more contemporary diasporas. The problem with this argument is that it is very much a Jewish nationalist position which also argues that the European Jewish diaspora should be superseded after the Holocaust but, in this case, by the newly formed state of Israel. Such was the redemptive narrative applied to the state of Israel. This kind of supersessionism seems to me to be quite insidious and a dangerous way of thinking about things. Because it feeds into a progressivist western narrative where the new is always better, the new is always more interesting, the new always goes beyond history or transfigures history.

Stef Craps: $\quad$ I think I'm basically on the same page as Bryan in that I also believe in crossing boundaries in full awareness of all the pitfalls this entails. Bryan in his book also talks about what he calls "the anxiety of appropriation" ([3], p. xiv).

Bryan Cheyette: Yes, we seem to have simultaneously come up with a similar term! 
Stef Craps: $\quad$ In my book [2] I follow Michael Rothberg [15] in using the concept of metaphor to name a way of looking at history that insists on similarity and in so doing threatens to conflate distinct historical experiences. I oppose it to a metonymical view, which places different histories alongside one another and thus preserves the distance between them. I argue that we need to combine the two logics, that a metonymical view of history needs to supplement a metaphorical one. Bryan only mentions metaphor, not metonymy, but I think this is just a question of semantics rather than a fundamental disagreement.

Bryan Cheyette: Yes.

Stef Craps: What Bryan calls "metaphorical thinking" ([3], pp. xiii-xiv) is not unlike the oscillation between the two logics that I describe ([2], p. 89).

The reason why I tend to dwell on the risks involved in remembering across cultural and national boundaries, as I did in my talk this morning [31], is that many proponents of what Astrid Erll calls the "transcultural turn" in memory studies ([32], pp. 173-74) minimize them or ignore them altogether. Much work in transcultural memory studies, especially by American scholars, articulates a very hopeful vision. I'm thinking particularly of Daniel Levy and Natan Sznaider [33], Alison Landsberg [34] and Jeffrey Alexander [35]. Their work is characterized by a strong belief in the emancipatory potential, the cathartic or healing effects of remembering across cultural and national borders. Personally, I think a healthy dose of scepticism is called for. After all, very often Holocaust comparisons are used in ways that do not lead to greater transcultural understanding and the establishment of a universal human rights culture. I do think the notion that transcultural or transnational remembrance can have beneficial effects-in principle if certainly not always in practice - is worth considering, but not uncritically.

Another issue I want to raise is my growing discomfort with the centrality of the Holocaust in scholarship challenging disciplinary thinking. I wonder if by almost always taking the need to decentre the Holocaust as our starting point, we are not inadvertently reaffirming its centrality. I myself plead guilty in this regard: I also do this in much of my work, including in my talk this morning [31]. In fact, I don't think any individual scholar is to blame exactly, but if we all end up always taking the Holocaust as our point of comparison, it seems to me that our collective efforts to move beyond disciplinary thinking may prove counterproductive. After all, there is something profoundly paradoxical about considering one particular history to be uniquely suited to challenging the uniqueness paradigm. So again, I agree with Bryan about the need for more comparative work in memory and trauma studies, but I would add that it would be salutary and refreshing if a greater variety of histories were brought into contact with one another.

Alan Gibbs: $\quad$ Yes, I would not presume to add very much because it's not something I've given as much thought to. I agree with Stef's dose of healthy scepticism in that as 
cultural trauma studies emerged there were hopes that it would somehow unite conceptions of memory and different disciplines. I don't think these have been anywhere near achieved, I suppose partly due to differences being maintained between disciplines. The areas I am thinking of in particular would be literature, psychology and history in that their perspective on trauma seems to be still very disparate. The example I would cite would be to do with the experience of the perpetrator when it comes to trauma. I might say more about this later, but it is something that, for example, the discipline of history has looked at quite extensively, whereas it seems to me that when you come to literary studies, there is still a strong discomfort with even broaching the notion of the perpetrator.

Sonya Andermahr: Thank you. Now if we can discuss the implications for pedagogy, particularly thinking around the ethics of detachment and identification. Bryan, would you like to say a few words on this?

Bryan Cheyette: This issue came out of the University of Zaragoza conference [29], and I suppose it is a question I could throw open to the panel, who I am assuming teach trauma studies. It seems to me that when one teaches the kind of texts that deal with trauma and attempt to represent trauma, the last thing you want to do is to enable students to turn it into just another academic discipline, where they detach themselves from that trauma. So one of the things that I find very useful, as part of the assessment, is to give students a journal where they can move away from that sense of academic detachment.

There are other ways of critiquing questions of detachment. One form of cosmopolitanism, for instance, has been critiqued as being overly detached [36]. But those who are most self-conscious about their own particular traumas are aware that in some ways they are complicit with those who did the traumatizing when they split themselves by writing about their experiences from an objective or detached perspective. So there is a range of issues around those terms.

Alan Gibbs: I thought it was very interesting when that came up last week at the University of Zaragoza, this idea of actually getting students to admit a kind of emotional response as part of their response to a text.

Bryan Cheyette: Or at least to give them a space where they can engage emotionally with the texts.

Alan Gibbs:

Yes, I think that might make me re-think how I teach some of this material. I do tend, and I think this is just coming from a literary studies background, to encourage detachment. I am probably a little averse to emotional responses just because of so many years of training. Again, I suppose we could go back to this idea of a plethora of literary texts that do explore the notion of the perpetrator, or at least the 'grey zone', when it comes to trauma. And it is understandable that this more emotionally invested approach has found it distasteful to tackle some of 
these texts. I think that trauma theory's roots in Holocaust studies and psychology are especially relevant here.

But the fact is, these texts are published, and they are widely read. For example, the plethora of memoirs written by members of the American armed forces following their involvement in various conflicts. As a literary scholar, there is a kind of willful negligence in pretending that texts such as these do not exist. We cannot wish them away. I think what trauma theory and trauma studies can do more usefully is to develop methodologies for understanding these perpetrator trauma texts. For example, how does trauma operate differently for perpetrators? How is it represented differently in terms of narrative and aesthetic forms in these texts? Some work has been started on this. I have done a little bit in my book, and there is Michael Rothberg's, I think potentially very useful, concept of the "implicated subject" [37,38]. This is a figure somewhere between victim or sufferer and perpetrator. Here I believe are the beginnings of some interesting work.

Stef Craps: $\quad$ It seems to me that trauma studies has always been critical of detachment as a stance from which to approach painful histories. It is a basic assumption of much trauma theory that readers or viewers should be affected by trauma testimonies they read or view. There is an important affective or experiential dimension to reading or hearing about histories of suffering; it's not just about assimilating factual knowledge.

Of course, the risk involved in encouraging people to respond affectively to trauma testimonies is that they will over-identify with trauma survivors, appropriating their experience and ignoring its singularity. This is a risk of which trauma theorists have long been aware. People like Cathy Caruth, Dominick LaCapra, Jill Bennett and E. Ann Kaplan have warned against forms of affective involvement that do not respect and recognize alterity. They refer to these kinds of responses as "crude empathy", "facile empathy", or "empty empathy". Desirable empathy, by contrast, is called "empathic unsettlement" ([39], p. 135), "critical empathy" ([40], p. 21), or an "ethics of witnessing" ([41], p. 122). It's a kind of empathy-at-a-distance, which combines affect with critical awareness of the unbridgeable gap between self and other.

This is one trauma-theoretical orthodoxy that I'm quite comfortable with, as long as empathy is indeed checked and combined with a measure of critical distance. In fact, I tend to ask students to prepare for my classes on trauma literature by writing response pieces about the assigned readings, in which they can share their reading experience, if they wish to do so, provided that they also reflect on it. I share Bryan's scepticism about calls for detachment insofar as they devalue the affective, experiential dimension of relating to painful histories and embrace the idea of full objectivity, neutrality and aloofness. In Representing the Holocaust, LaCapra argued - and I think this is what you were also getting at, Bryan — that as 
a historian, one has to come to terms with one's transferential implication in one's object of study, which means: being vigilant not to repeat the problems one is studying ([42], p. 46). He called pure objectification-positioning oneself as a complete outsider - a denial of transference. It actually repeats the kind of thinking that allowed the Nazis to dehumanize the Jews and do what they did in the first place.

I will add, though, that, like Alan, I think there has been too much of an emphasis in trauma studies on identification with victims and too little emphasis on identification with perpetrators. While it's important, of course, to pay attention to the experience of victimhood, it's also important to try to understand the perpetrator's perspective. If we only ever identify with victims - if we only ever place ourselves on the side of the angels, as it were-we effectively deny our own complicity in violent histories and our own capacity for evil. As Rick Crownshaw has argued, the universalization of the victim's identity turns the perpetrator into an unknowable, mysterious figure, who has nothing to do with us, and renders the processes of perpetration incomprehensible ([43], p. 77). So, paradoxically, instead of preventing the repetition of a violent past, trauma studies may actually end up facilitating its recurrence. Again, I don't think any individual trauma theorist is to blame, but if the field as a whole is heavily skewed towards exploring victimhood rather than focusing on perpetration, I do think there is a problem.

The fact that I believe in the value of "empathic unsettlement" ([39], p. 135) also means that I'm very sceptical of the campaign for "trigger warnings" that has swept the US academy over the last year or so [44]. The idea is that professors should give students advance warning if they are planning to confront them with potentially disturbing or upsetting material, and allow them to skip classes that could make them feel uncomfortable. Of course, it's not a black-and-white situation. I do think it's reasonable for a rape survivor, for example, to ask a professor for a heads-up if the reading list includes a text with graphic descriptions of sexual violence. And, of course, students have the right to walk out of a classroom. But generalized trigger warnings are a different matter; there is real harm in utilizing them, it seems to me. I believe that education is basically all about being disturbed, about being made to leave one's comfort zone, about being shaken out of one's habitual assumptions. Discomfort is essential to education; it's what drives it. So you want to be very careful not to tamper with that basic principle. Instead of protecting students, general trigger warnings may prevent them from getting an education.

Sonya Andermahr: So we move to our final question then, which concerns the future of the field. Alan, if you'd like to predict the future for us?

Alan Gibbs: Obviously, it is a difficult question, and impossible really to answer this without just extrapolating from the present. I can see it going two ways. On the one hand, I 
think there is a lot more flexibility in the concepts of trauma we have seen emerging in the last 5 to 10 years. There are clear signs now that we are moving beyond the narrower and more prescriptive ways of understanding trauma and conceptualizing how trauma is represented or should be represented. Again thinking back to the Zaragoza "Memory Frictions" conference, Robert Eaglestone's keynote address raised an interesting point. Namely, that the concept of trauma is becoming so wide now, including things like 'slow violence', 'insidious trauma', that the question needs to be raised as to whether we are actually still talking about something that we can label trauma anymore. His feeling seemed to be that perhaps we should come up with new terms [45].

My feeling is more that we can still understand these phenomena according to a concept of trauma. But at the same time, I would admit that as its definition stretches, it begins to become less meaningful as a concept. On the other hand, maybe we are reaching a crisis point in considering the very notion of trauma. I am reflecting on an article that was published towards the end of last year, Joshua Pederson's "Speak Trauma", which came out in the October 2014 issue of Narrative [46]. This presented a serious challenge to some of the most cherished notions of cultural trauma theory. It was very much an attack on some of Cathy Caruth's work and its basis in neurological research that Pederson was very keen to debunk [47,48], connecting with and drawing upon Richard McNally's criticism of Bessel A. Van der Kolk's work [49]. Pederson's essay challenges this dominant idea that belatedness is necessarily part of trauma, that afterwardness is part of traumatic memory. It also presents a challenge to the idea that traumatic memory is necessarily different, that it is registered differently on the brain to regular memory. Now, this is such a foundation of cultural trauma theory that if, as appears to be the case, there is new research challenging even this, then there is an awful lot that is going to have to be re-thought. Pederson's article encourages us to recognize the difference between an inability to remember the traumatic memory and an inability or a refusal to narrate it. I think this is an important distinction, one that I have urged in my own work ([5], p. 75), and which ought to be very influential and important for the future of the field.

As Stef suggests in his work, I think we also need a greater sensitivity towards the context of the text. I have been looking at this in my own field of contemporary American writing and suggesting that there has been the emergence of a kind of neo-naturalism for the representation of trauma, partly as a kind of reaction against the traumatic avant-garde. Within this context, it is also important to consider notions of agency which have become increasingly important in contemporary American life. For example, post 9/11, there is a discernible discomfort amongst a large part of the population in accepting responsibility for the government's actions. So this emergence of a new form of naturalism frequently incorporates a kind of determinism that denies characters free will, thus 
removing responsibility for their actions. This is again a very interesting, quite local manifestation of a particular kind of trauma text that we are going to have to be flexible to account for. So, there are lots of possibilities opening up but also lots of potential problems for the future of the field.

Sonya Andermahr: Great, thank you. Bryan?

Bryan Cheyette: One of my professors taught me that "You can predict everything apart from the future!" The quest for new terms and new ways of thinking is certainly something that characterizes our moment, and I find Alan's use of the term 'crisis-point' in this context very interesting. We are in a kind of crisis, we are post-postmodern, post-theory, post-postcolonialism, I mean we're even post-post! We are looking for new terms and new ways of thinking about our times as well as new vocabularies. So we are, it seems, back to the question of newness, but that does not mean, as I have stressed, that we have to evacuate a historical understanding of the issues which we are discussing. In all of our books, we are looking for new ways of trying to think about our present moment while, it seems to me, aiming for a longer temporal and spatial reach. I agree absolutely with Stef about the question of the centrality of the Holocaust, which was not the case, I hasten to add, when I first started teaching! But the Holocaust has become central to western ways of thinking about history, which is largely because it has been Americanized, an odd phenomenon which complements Alan's work. So new comparative thinking will hopefully move away from that centralization without simply repeating the centralization via de-centralizing it, as Stef has argued. Maybe one example is the panel we had on the Aborigine writers and the issue of The Stolen Generations led by Maram Samman [50] and Justine Seran [51]. I was struck by that whole colonial or neo-colonial model of assimilation, the model of institutionalizing people, which applies across all minority ethnic histories and minorities in general. So you could also look at insane asylums in the United States and look at what the Irish did to young women without families to show that such histories often take place within so-called 'liberal' societies. My approach would be to make these kinds of linkages and comparisons beyond particular disciplines. I do think that 'trauma' and 'trauma studies' is pretty exhausted as a term, and I can see why we are getting the kind of critiques from someone like Joshua Pederson [46].

In regards to the future, I agree with Stef that looking at the risks of bringing together different histories and cultures should be at the centre of the comparative thinking enterprise. A lot of the examples that I look at in my own book, by V.S. Naipaul, Anita Desai, Salman Rushdie and others, might be said to have actually reinforced old discourses instead of being a celebratory bringing together of different histories [3]. In terms of a comparative project there are always two ways of looking at the metaphorical or metonymic turn. One approach is to bow to the risk of metaphorical thinking and to stay within particular histories of victimhood, 
and the second approach, which I champion in Diasporas of the Mind, is to make connections across nations, communities and cultures so as to enlarge our sense of self and include 'other others' in the pantheon of what it is to be human. But we should certainly be self-aware of the tension between risk-taking, which downplays differences, and celebrating inter-connectedness, which is on the side of a new decolonized humanism.

Sonya Andermahr: And finally, Stef, the last word is for you.

Stef Craps:

I am quite hopeful about the future of the field, which is something that I probably wouldn't have said 10 years ago. Trauma theory had seemed to me to be stagnating somewhat since its early burst of creative energy in the 1990s. It's not as if nothing was happening, but I saw little evidence of conceptual innovation, of new ideas and theoretical breakthroughs, in the early 2000s. However, in the course of the last few years I've seen various signs of renewal and continuing relevance. It seems to me-and this ties in with what Alan was saying earlier-that the tenets laid down by the founders of trauma studies are increasingly being questioned and that, as a result, the field is becoming more diversified and pluralistic. I think the three of us have each done our bit to help make this happen, along with many others, of course.

Some exciting trends that I see are first of all the tendency to study trauma as a global rather than a European or Western phenomenon, which we've been talking about today. I think it's fair to say that this trend is by now firmly established, though, as I said, it's my sense that we're still only at the beginning of this process.

Secondly, and this has also come up already, attempts are being made to move beyond normative trauma aesthetics. The notion that a modernist aesthetic of fragmentation and aporia is uniquely suited to the task of bearing witness to trauma is losing ground. Trauma studies is confronting its aesthetic elitism problem and becoming more open to and appreciative of alternative modes of representation. This trend was spearheaded by Roger Luckhurst's The Trauma Question [52], which discussed the trauma canon alongside popular-cultural engagements with trauma, such as Stephen King novels and popular trauma memoirs. This has been taken further by Anne Rothe in a book called Popular Trauma Culture that looks at misery memoirs and daytime TV shows such as Jerry Springer and Oprah [53]. I myself have recently also supervised a $\mathrm{PhD}$ dissertation on trauma in video games, a medium that had long been neglected by trauma scholars. Alan's scathing critique of the ossified conventions of supposedly unconventional trauma writing is arguably the final nail in the coffin of the narrow trauma aesthetic to which the field has adhered for too long.

A third trend, which I'm particularly excited about and which Alan has also mentioned, is the shift or broadening of focus from victim trauma to perpetrator trauma: the tendency to no longer limit one's enquiry to the experiences of victims 
but to also take on board those of perpetrators as well as other categories of people implicated in traumatic events or histories. The notion that perpetrators can be trauma sufferers is still controversial, though, mostly because of the persistent tendency to conflate trauma and victimhood. The suspicion is that by claiming that a perpetrator has been traumatized, one is actually claiming victim status for him or her, exculpating him or her, excusing his or her crimes. However, as I see it, engaging with portrayals of perpetrators and various in-between groups is not about exonerating them (or, at least, it doesn't have to be that way) but about counter-acting a questionable tendency in trauma studies to over-identify with innocent victimhood, which, as I was saying earlier, risks blinding us to our own complicity and potential for evil.

A fourth trend, and I'll close with this, is an increasing awareness of the limits of trauma: attempts are being made to save the field from hubristic overreach by recognizing limits to its usefulness and legitimacy. Trauma theory sometimes overestimates its ability to diagnose, and even solve, the world's problems. It's increasingly being recognized - most eloquently, perhaps, by Michael Rothberg in his preface to The Future of Trauma Theory [54] - that trauma is not always the only or best lens for exploring complex global problems; trauma studies doesn't hold the key to understanding them, let alone to fixing them. It is but one possible mode of enquiry among others, valuable but only in consort with other approaches and methodologies, which it cannot and must not displace.

\section{Conflicts of Interest}

The authors declare no conflict of interest.

\section{References and Notes}

1. For a full contextualization of this round-table discussion and the terms being used see: Sonya Andermahr. "Decolonizing Trauma Studies: Trauma and Postcolonialism-Introduction." Humanities 4 (2015): 500-5.

2. Stef Craps. Postcolonial Witnessing: Trauma Out of Bounds. Basingstoke and New York: Palgrave Macmillan, 2013.

3. Bryan Cheyette. Diasporas of the Mind: Jewish and Postcolonial Writing and the Nightmare of History. New Haven: Yale University Press, 2013.

4. Bryan Cheyette. The Oxford History of the Novel in English, Volume Seven: British and Irish Fiction since 1940. Oxford: Oxford University Press, 2016, forthcoming.

5. Alan Gibbs. Contemporary American Trauma Narratives. Edinburgh: Edinburgh University Press, 2014.

6. Robert L. Spitzer. DSM-III-R Casebook: A Learning Companion to the Diagnostic and Statistical Manual of Mental Disorders, 3rd ed., rev. Washington: American Psychiatric Press, 1989. 
7. Allan Young. The Harmony of Illusions: Inventing Post-Traumatic Stress Disorder. Princeton: Princeton University Press, 1995.

8. Derek Summerfield. The Impact of War and Atrocity on Civilian Populations: Basic Principles for NGO Interventions and a Critique of Psychosocial Trauma Projects. London: Overseas Development Institute, 1996.

9. Frantz Fanon. Black Skin, White Masks. New York: Grove Press, 1967.

10. Gert Buelens, Sam Durrant, and Robert Eaglestone, eds. The Future of Trauma Theory: Contemporary Literary and Cultural Criticism. London and New York: Routledge, 2014.

11. Michelle Balaev, ed. Contemporary Approaches in Literary Trauma Theory. New York: Palgrave Macmillan, 2014.

12. Sindiwe Magona. Mother to Mother. Boston: Beacon Press, 1999.

13. Aminatta Forna. The Memory of Love. New York: Atlantic Monthly Press, 2010.

14. Stef Craps. "Beyond Eurocentrism: Trauma Theory in the Global Age." In The Future of Trauma Theory: Contemporary Literary and Cultural Criticism. Edited by Gert Buelens, Samuel Durrant and Robert Eaglestone. New York: Routledge, 2013, pp. 45-61.

15. Michael Rothberg. Multidirectional Memory: Remembering the Holocaust in the Age of Decolonization. Stanford: Stanford University Press, 2009.

16. Mark Mazower. Hitler's Empire: Nazi Rule in Occupied Europe. London: Allen Lane, 2008.

17. Aimé Césaire. Discourse on Colonialism. New York: Monthly Review Press, 2000.

18. Hannah Arendt. The Origins of Totalitarianism. New York: Harcourt Brace, 1951.

19. Philip Roth. Sabbath's Theatre. London: Vintage Books, 2008.

20. Philip Roth. The Plot against America. Boston: Houghton Miffin, 2004.

21. Sonya Andermahr. "Decolonizing Narratives of 1940s Britain in Andrea Levy's Small Island." Paper presented at the Decolonizing Trauma Studies Symposium, The University of Northampton School of The Arts, Northampton, UK, 15 May 2015.

22. Béatriz Perez-Zapata. "Of Events and Insiduousness: An Analysis of Trauma Theory in the Work of Zadie Smith." Paper presented at the Decolonizing Trauma Studies Symposium, The University of Northampton, School of The Arts, Northampton, UK, 15 May 2015.

23. Zadie Smith. The Embassy of Cambodia. London: Hamish Hamilton, 2013.

24. Andrea Levy. Small Island. New York: Picador, 2005.

25. Jonathan Boyarin. Thinking in Jewish. Chicago: University of Chicago Press, 1996.

26. Gayatri Chakravorty Spivak. Death of a Discipline. New York: Columbia University Press, 2003.

27. "Edward Said/Ari Shavit Interview." Ha'aretz, 18 August 2000. In Power, Politics and Culture: Interviews with Edward W. Said. Edited by Gauri Viswanathan. New York: Pantheon Books, 2001.

28. Edward W. Said. The Question of Palestine. New York: Random House, 1979.

29. Bryan Cheyette. "The Contemporary Novel, Reality Hunger and the Memory Boom." Keynote Lecture at the "Memory Frictions: Conflict-Negotiation-Politics" Conference, The University of Zaragoza, Zaragoza, Spain, 6-8 May 2015.

30. Robin Cohen. Global Diasporas: An Introduction. London: Routledge, 2001.

31. Stef Craps. "The Holocaust and Comparative Genocide in the Poetry of Sherman Alexie." Keynote lecture at the Decolonizing Trauma Studies Symposium, The University of Northampton School of The Arts, Northampton, UK, 15 May 2015. 
32. Astrid Erll. Memory in Culture. Basingstoke and New York: Palgrave Macmillan, 2011.

33. Daniel Levy, and Natan Sznaider. The Holocaust and Memory in the Global Age. Philadelphia: Temple University Press, 2006.

34. Alison Landsberg. Prosthetic Memory: The Transformation of American Remembrance in the Age of Mass Culture. New York: Columbia University Press, 2004.

35. Jeffery C. Alexander. "The Social Construction of Moral Universals." European Journal of Social Theory 5 (2002): 5-85.

36. Amanda Anderson. The Powers of Distance: Cosmopolitanism and the Cultivation of Detachment. Princeton: Princeton University Press, 2001.

37. Michael Rothberg. "Trauma Theory: Implicated Subjects and the Question of Israel/Palestine." Profession, 2 May 2014. Available online: https://profession.commons.mla.org/2014/05/02/ trauma-theory-implicated-subjects-and-the-question-of-israelpalestine/ (accessed on 31 July 2015).

38. Michael Rothberg. The Implicated Subject: Beyond Victims and Perpetrators. Stanford: Stanford University Press, 2015 forthcoming.

39. Dominick LaCapra. History in Transit: Experience, Identity, Critical Theory. Ithaca and New York: Cornell University Press, 2004.

40. Jill Bennett. Empathic Vision: Affect, Trauma and Contemporary Art. Stanford: Stanford University Press, 2005.

41. E. Ann Kaplan. Trauma Culture: The Politics of Terror and Loss in Media and Literature. New Brunswick: Rutgers University Press, 2005.

42. Dominick LaCapra. Representing the Holocaust: History, Theory, Trauma. Baltimore and London: Johns Hopkins University Press, 1994.

43. Richard Crownshaw. "Perpetrator Fictions and Transcultural Memory." Parallax 17 (2011): 75-89.

44. Jennifer Medina. "Warning: The Literary Canon Could Make Students Squirm." The New York Times, 17 May 2014. Available online: http://www.nytimes.com/2014/05/18/us/warning-theliterary-canon-could-make-students-squirm.html?_r=0 (accessed on 31 July 2015).

45. Robert Eaglestone. "Telos and Trauma." Keynote lecture at the "Memory Frictions: Conflict-Negotiation-Politics" Conference, The University of Zaragoza, Zaragoza, Spain, 6-8 May 2015.

46. Joshua Pederson. "Speak Trauma: Towards a Revised Understanding of Literary Trauma Theory." Narrative 22 (2014): 333-53.

47. Cathy Caruth. Trauma: Explorations in Memory. Baltimore and London: John Hopkins University Press, 1995.

48. Cathy Caruth. Unclaimed Experience: Trauma, Narrative and History. Baltimore and London: John Hopkins University Press, 1996.

49. Richard J. McNally. Remembering Trauma. Cambridge and London: Harvard University Press, 2003.

50. Maram Samman. "The Aboriginal Stolen Generations: A Study of (Dis)integration of Identity in Selected Canadian and Australian Plays." Paper presented at the Decolonizing Trauma Studies Symposium, The University of Northampton School of The Arts, Northampton, UK, 15 May 2015. 
51. Justine Seran. "II cannot retract what has been written, it's no longer mine': Stolen Generations Trauma and Collective Memoirs." Paper presented at the Decolonizing Trauma Studies Symposium, The University of Northampton School of The Arts, Northampton, UK, 15 May 2015.

52. Roger Luckhurst. The Trauma Question. Oxford and New York: Routledge, 2008.

53. Anne Rothe. Popular Trauma Culture: Selling the Pain of Others in the Mass Media. New Brunswick: Rutgers University Press, 2011.

54. Michael Rothberg. "Beyond Tancred and Clorinda: Trauma Studies for Implicated Subjects." In The Future of Trauma Theory: Contemporary Literary and Cultural Criticism. Edited by Gert Buelens, Samuel Durrant and Robert Eaglestone. New York: Routledge, 2013, pp. xi-xviii.

(C) 2015 by the authors; licensee MDPI, Basel, Switzerland. This article is an open access article distributed under the terms and conditions of the Creative Commons Attribution license (http://creativecommons.org/licenses/by/4.0/). 